\title{
EFEKTIVITAS PERAWATAN LUKA TEKNIK BALUTAN WET- DRY DAN MOIST WOUND HEALING PADA PENYEMBUHAN ULKUS DIABETIK.
}

\author{
Maria Imaculata Ose ${ }^{1,}$ Putri Ayu Utami ${ }^{2}$, Ana Damayanti ${ }^{3}$ \\ 1,2,3 Jurusan Keperawatan Fakultas Ilmu Kesehatan Universitas Borneo Tarakan \\ *Email :onijuntak@gmail.com
}

\begin{abstract}
ABSTRAK
Ketidakseimbangan glukosa dalam darah menimbulkan dampak gangguan pada neuropati yang berpotensi terjadinya luka diabetes. Salah Satu komplikasi diabetes melitus adanya luka ulkus yang menyebabkan 50\% hingga 75\% harus amputasi. Perawatan luka dewasa ini di ruang perawatan rumah sakit masih cenderung menggunakan metode balutan kasa "Wet-Dry"(Basah-kering), perawatan luka telah mengalami perkembangan yang sangat pesat terutama dalam dua dekade terakhir ini. Teknik perawatan luka terkini "Moist Wound Healing". Tujuan penelitian ini untuk melihat efektivitas penyembuhan luka dengan membandingkan penggunaan balutan dengan teknik Wet-Dry dan dengan teknik balutan Moist Wound Healing. Jenis penelitian ini adalah kuantitatif dengan menggunakan desain Quasi eksperimental. Populasi adalah seluruh pasien diabetes yang mengalami ulkus. Teknik pengambilan sampel menggunakan Purposive Sampling sehingga diperoleh 18 responden yang menggunakan perawatan luka dengan teknik wet-dry dan 15 responden ulkus diabetic yang dilakukan perawatan luka dengan teknik Moist Wound Healing. Hasil : Data variabel berdistribusi normal setelah diuji dengan Saphiro-Wilk. Uji t-berpasangan menunjukan nilai signifikan $\mathrm{p}=0,004$ yang mana nilai $\mathrm{p}$ Value $<0,05$ sehingga ini menunjukkan bahwa terdapat perbedaan yang antara kelompok penyembuhan luka dengan perawatan luka dengan teknik Wet dry dengan kelompok perawatan luka Moist Wound Healing. Kesimpulan dari penelitian ini perawatan luka pada ulkus diabetik dengan teknik moist healing lebih cepat proses penyembuhannya sehingga pasien mendapatkan perawatan lebih efektif dan efisien baik dari segi waktu dan biaya.
\end{abstract}

Kata Kunci : Ulkus, Diabetic, Wet-dry, Moist Wound Healing.

\begin{abstract}
The Effectiveness Of Wet-Dry And Moist Wound Healing Techniques On Diabetic Ulcer Healing. Glucose imbalance in the blood affects the interference of neuropathy which potentially caused injury to diabetes. One complication of diabetes mellitus of ulcer wounds that cause 50\% to $75 \%$ should be amputated. Today's wound care in hospital wards still tends to apply the "Basah - Kering" (Wet-dry) screening method. Wound care has developed rapidly especially in the last two decades. The latest wound treatment technique "Moist Wound Healing". The purpose of this research is to see the effectiveness of wound healing by comparing the use of bandage with Wet-Dry technique to with Moist Wound Healing dressing technique. This type of research is quantitative using the Quasi experimental design. The population is all diabetic patients who have ulcers. The sampling technique used Purposive Sampling to get 18 respondents who apply wet-dry wound treatment and 15 respondents of diabetic ulcer who performed wound treatment with Moist Wound Healing technique. Result: Variable data distribute normally after tested with Saphiro-Wilk. The paired t-test showed significant value $p=0,004$ which was $p$ value $<0,05$ so it showed that there was a difference between wound healing group and wet dry treatment with wound healing wound treatment group. The conclusion of this research treatment of wounds in diabetic ulcers with moist healing technique is faster in the healing process so that the patients get treatment more effectively and efficiently both in terms of time and cost.
\end{abstract}

Keywords: Ulcers, Diabetic, Wet-dry, Moist Wound Healing. 


\section{Pendahuluan}

Diabetes Mellitus merupakan sekelompok kelainan heterogen yang ditandai oleh kenaikan kadar glukosa dalam darah atau hiperglikemia. Pada diabetes, kemampuan tubuh untuk beraksi terhadap insulin dapat menurun, atau pankreas dapat menghentikan sama sekali produksi insulin. Keadaan ini menimbulkan hiperglikemia yang mengakibatkan komplikasi metabolik akut seperti Diabetes ketoasidosis dan sindrom hiperglikemia yang mengakibatkan sindrome hipeglikemia hiperosmoler nonketotik (HHNK) dan pada jangka panjang menyebabkan mikrovaskuler yang kronis (penyakit ginjal dan mata) dan komplikasi makrovaskuler yang mencakup infark miokard, stroke dan penyakit vaskuler perifer. Salah Satu komplikasi diabetes melitus adanya luka ulkus yang menyebabkan 50\% hingga $75 \%$ harus amputasi. Ketidakseimbangan glukosa dalam darah menimbulkan dampak gangguan pada neuropati yang berpotensi terjadinya luka diabetes (Soewondo,dkk 2013). Di perkirakan penderita DM memiliki resiko untuk mengalami ulkus diabetik sebagai akibat dari ketidakseimbangan glukosa darah yang berdampak pada neuropati. Rangkaian kejadiaan yang khas dalam proses ulkus diabetik pada kaki dimulai dengan cedera pada jaringan lunak kaki, pembentukan fisura antara jari-jari kaki atau didaerah kulit yang kering atau pembentukan sebuah kalus. Masalah pada kaki diabetik misalnya ulserasi, infeksi dan gangren merupakan penyebab umum perawatan di rumah sakit bagi para penderita diabetes. Perawatan rutin ulkus, pengobatan infeksi, amputasi dan perawatan di Rumah Sakit membutuhkan biaya yang sangat besar tiap tahun dan menjadi beban yang sangat besar dalam sistem pemeliharan kesehatan. (Smeltzer dan Bare, 2002).

Ulkus diabetes disebabkan oleh beberapa faktor yaitu neuropati, trauma, deformitas kaki, tekanan tinggi pada telapak kaki dan penyakit vaskuler. Pemeriksaan dan klasifikasi ulkus diabetik yang menyeluruh dan sistematik dapat membantu memberikan arahan yang adekuat. Ulkus diabetik dapat juga disebabkan oleh tekanan yang terus menerus atau adanya gesekan yang mengakibatkan kerusakan pada kulit Gesekan bisa mengakibatkan terjadinya abrasi dan merusak permukaan epidermis kulit (Parmet, 2005). Secara fisiologis penyembuhan luka terjadi dengan cara yang sama pada semua pasien, dengan sel kulit dan jaringan 
kembali secara cepat atau lambat. Perkembangan pengetahuan tentang teknik perawatan luka terkini menjadi trend tersendiri di dunia keperawatan. Perawat sebagai pemberi layanan diharapkan memenuhi kebutuhan pasien/masyarakat akan pentingnya pemanfaatan ilmu terkini. Pemahaman Perawat yang benar tentang teknik perawatan luka terkini akan meningkatkan kualitas pelayanan kesehatan. Banyak teknik perawatan luka dikembangkan diberbagai rumah sakit. Perawatan luka dewasa ini, cenderung menggunakan metode balutan kasa "Wet-dry"(Basah-kering), BasahKering digunakan khusus untuk debridemen pada dasar luka, normal salin digunakan untuk melembabkan kasa, kemudian dibalut dengan kasa kering. Ketika kasa lembab menjadi kering, akan menekan permukaan jaringan, yang berarti segera harus diganti dengan balutan kering berikutnya. Hal ini mengakibatkan tidak hanya pertumbuhan jaringan sehat yang terganggu, tetapi juga menimbulkan rasa nyeri yang berlebihan, metode Wet-dry dianggap sebagai metode debridemen mekanik dan diindikasikan bila ada sejumlah jaringan nekrotik pada luka. (Perry dan Potter, 2002). Teknik perawatan luka terkini menggunakan prinsip lembab (moist) atau sering digunakan istilah "Moist Wound Healing". Metode ini secara klinis akan meningkatkan epitelisasi 30-50\%, meningkatkan sintesa kolagen sebanyak $50 \%$, rata-rata re-epitelisasi dengan kelembaban 2-5 kali lebih cepat serta dapat mengurangi kehilangan cairan dari atas permukaan luka (Wahidin, 2013). Moist Wound Healing adalah mempertahankan isolasi lingkungan luka yang tetap lembab dengan menggunakan balutan penahan-kelembaban, oklusive dan semi oklusive sehingga penyembuhan luka dan pertumbuhan jaringan dapat terjadi secara alami, dapat mempercepat penyembuhan $45 \%$ dan mengurangi komplikasi infeksi dan pertumbuhan jaringan parut residual. Penanganan luka ini saat ini terutama untuk luka kronik, seperti venous leg ulcers, pressure ulcers, dan diabetic foot ulcers. Teknik ini memiliki keuntungan luka cepat sembuh, kualitas penyembuhan baik serta dapat mengurangi biaya perawatan luka. Hal ini sangat penting bagi perawat untuk dapat mengembangkan dan mengaplikasikannya di lingkungan perawatan khususnya perawatan luka yang jelas sangat memberikan kepuasan bagi kesembuhan luka pasien (Ismail dkk, 2009). 
Perawatan luka secara benar sebagai upaya untuk membantu mempercepat proses penyembuhan perlu dikembangkan. Pada penelitian ini penulis ingin membandingkan bagaimana pengaruh perawatan luka ulkus diabetik dengan teknik balutan kasa Basah-Kering (Wet-dry, dan teknik lembab (Moist Wound Healing) dengan

\section{Metode}

Penelitian merupakan penelitian kuantitatif dengan desain penelitian quasy experiment dengan kelompok pembanding (control time series design). Penelitian ini dengan rancangan rangkaian waktu, hanya dengan menggunakan kelompok pembanding (Notoatmodjo, 2005). Populasi diambil di RSUD Tarakan. Pada bulan OktoberDesember 2013 ada 18 responden yang menggunakan perawatan luka dengan teknik Wet-dry dan 15 responden ulkus diabetic yang dilakukan perawatan luka dengan teknik moist wound Healing. Pada penelitian ini, peneliti menggunakan teknik purposive sampling. Kriteria Inkulsi 1) pasien dengan ulkus diabetik grade II sampai dengan grade IV menurut klasifikasi Wagner, 2) hemodinamik stabil, 3). Kadar gula darah stabil. Dalam menggunakan metode hydrocoloid dreesing terhadap percepatan penyembuhan luka (Mulder, 1995). Hasil dari penelitian ini di harapkan dapat memberikan masukan bagi perawat dalam melaksanakan intervensi perawatan luka ulkus diabetik.

penelitian ini, membagi dua kelompok Perawatan luka dengan menggunakan metode balutan basah-kering (Wet-dry) pada pasien diabetes melitus dirawat di Ruang Flamboyan dan ruang Dahlia RSUD Tarakan dan balutan lembab (Moist wound healing) pada pasien Homecare di Kota Tarakan. Penyembuhan luka yang dilakukan penilaian dengan menggunakan lembar observasi Bates-Jansen, yang mengevaluasi ukuran luka, kedalaman luka, keadaan tepi luka, terowongan pada luka, tipe jaringan nekrotik, luas jaringan nekrotik, jenis eksudat, jumlah eksudat, keadaan kulit sekitar luka, oedem perifer, ukuran jaringan granulasi, indurasi jaringan perifer dan ukuran epitelisasi. Analisa bivariat adalah analisis secara simultan dari dua variabel. Sebelum dilakukan uji bivariat, peneliti melakukan uji normalitas data dengan menggunakan Uji Saphiro-Wilk karena responden kurang dari 50 
Ose, M.I.,Utami, P.A, \& Damayanti, A., Efektivitas Perawatan Luka Teknik Balutan WetDry Dan Moist Wound Healing Pada Penyembuhan Ulkus Diabetik

(Dahlan Sopiyudin, 2011). Dan hasil yang di dapatkan pada nilai probabilitas kurang dari taraf signifikan 0,05 atau $5 \%$ yang menjelaskan bahwa data tersebut berdistribusi normal. Pada Tahap uji hipotesis dengan Uji t-berpasangan. Uji

\section{Hasil}

Perawatan luka dilakukan selama satu minggu, pada setiap hari dilakukan evaluasi. Luka dengan perawatan menggunakan Wet-dry dilakukan evaluasi perhari. Kondisi luka ulkus ini membandingkan dua mean antar variabel. Dengan uji ini didapatkan hasil nilai probabilitas < taraf signifikan $5 \%$ atau $0,05 \%$ sehingga dapat ditarik suatu kesimpulan adanya perbedaan dalam dua kelompok tersebut.

dengan keadaan basa dan kotor maka akan dilakukan perawatan luka perhari. Hasil pengkajian dari karakteristik luka dari dua teknik tersebut sebagai berikut (gambar tabel 2)

Tabel 2. Karateristik Perkembangan Luka

\begin{tabular}{|c|c|c|c|c|c|}
\hline Karakteristik & Kelompok & $\mathbf{N}$ & Rata-Rata & SD & P Value \\
\hline \multirow[t]{2}{*}{ Ukuran Luka, } & Wet Dry & 18 & 2,89 & 1,278 & \multirow[t]{2}{*}{0,081} \\
\hline & Moist Wound Healing & 15 & 1,60 & .737 & \\
\hline Kedalaman & Wet Dry & 18 & 2,11 & 1,079 & \multirow[t]{2}{*}{0,625} \\
\hline Luka, & Moist Wound Healing & 15 & 1,67 & .724 & \\
\hline Keadaan Tepi & Wet Dry & 18 & 2,33 & 1,328 & \multirow[t]{2}{*}{0.72} \\
\hline Luka, & Moist Wound Healing & 15 & 1,47 & .743 & \\
\hline Terowongan & Wet Dry & 18 & 2,61 & 1,420 & \multirow[t]{2}{*}{0,001} \\
\hline Pada Luka, & Moist Wound Healing & 15 & 1,47 & .743 & \\
\hline Tipe Jaringan & Wet Dry & 18 & 3,39 & 1,420 & \multirow[t]{2}{*}{0,002} \\
\hline Nekrotik, & Moist Wound Healing & 15 & 1,53 & .640 & \\
\hline Luas Jaringan & Wet Dry & 18 & 2,72 & .895 & \multirow[t]{2}{*}{0,648} \\
\hline Nekrotik, & Moist Wound Healing & 15 & 2,00 & 1,069 & \\
\hline \multirow[t]{2}{*}{ Jenis Eksudat, } & Wet Dry & 18 & 3,17 & 1,339 & \multirow[t]{2}{*}{0,081} \\
\hline & Moist Wound Healing & 15 & 1,60 & .828 & \\
\hline Jumlah & Wet Dry & 18 & 2,67 & 1,138 & \multirow[t]{2}{*}{0,129} \\
\hline Eksudat, & Moist Wound Healing & 15 & 1,73 & .704 & \\
\hline Keadaan Kulit & Wet Dry & 18 & 2,94 & 1,392 & 0,001 \\
\hline Sekitar Luka, & Moist Wound Healing & 15 & 1,47 & .516 & \\
\hline \multirow[t]{2}{*}{ Oedem Perifer, } & Wet Dry & 18 & 2,72 & 1,274 & \multirow[t]{2}{*}{0,012} \\
\hline & Moist Wound Healing & 15 & 1,53 & .604 & \\
\hline Ukuran & Wet Dry & 18 & 2,89 & 1,491 & \multirow[t]{3}{*}{0,012} \\
\hline Jaringan & Moist Wound Healing & 15 & 1,73 & .704 & \\
\hline Granulasi, & & & & & \\
\hline Indurasi & Wet Dry & 18 & 2,72 & 1,274 & \multirow[t]{2}{*}{0,006} \\
\hline Jaringan Perifer & Moist Wound Healing & 15 & 1,53 &, 640 & \\
\hline Ukuran & Wet Dry & 18 & 2,89 & 1,323 & \multirow[t]{2}{*}{0,091} \\
\hline Epitelisasi & Moist Wound Healing & 15 & 1,60 & .737 & \\
\hline
\end{tabular}

Setelah dilakuan perawatan luka dan evaluasi pada hari ketiga didapatkan karakteristik luka ulkus pada dua teknik perawatan luka dengan menggunakan 
teknik Wet-dry maupun Moist Wound Healing meliputi ukuran luka, kedalaman luka, keadaan tepi luka, terowongan pada luka, tipe jaringan nekrotik, luas jaringan nekrotik, jenis eksudat, jumlah eksudat, keadaan kulit sekitar luka oedem perifer, ukuran jaringan granulasi, indurasi jaringan perifer dan ukuran epitelisasi. Uji

kenormalan data menunjukan bahwa karakteristik tersebut berdistriusi normal

Perbandingan efektifitas

\section{penyembuhan luka}

Hasil analisa menunjukan bahwa ratarata efektifitas penyembuhan luka pada kelompok perawatan luka dengan menggunakan teknik Wet-dry sebesar 2,33 sedangkan pada penyembuhan luka dengan teknik Moist Wound Healing rata-rata 1,40. Uji t-berpasangan menunjukan nilai signifikan $\mathrm{p}=0,004$ sehingga data dapat diuji dengan t-tidak berpasangan. Berdasarkan uji t-tidak berpasangan diperoleh $\mathrm{p}$ value $>0,5$ disimpulkan bahwa ada perbedaan pada karakteristik untuk ukuran luka, kedalaman luka, keadaan tepi luka, luas jaringan nekrotik, jenis eksudat, jumlah eksudat, oedem perifer, ukuran jaringan granulasi, indurasi jaringan perifer dan ukuran epitelisasi.

yang mana nilai $\mathrm{p}$ Value $<0,05$ sehingga ini menunjukkan bahwa terdapat perbedaan yang antara kelompok penyembuhan luka dengan perawatan luka dengan teknik Wet-dry dengan kelompok perawatan luka Moist Wound Healing.

Tabel 3 Rerata perbandingan efektifitas penyembuhan luka

\begin{tabular}{cccccc}
\hline & n & Mean & SD & $\boldsymbol{t}$ & $\boldsymbol{p}$ Value \\
\hline Wet Dry & 18 & 2,33 &, 485 & 5,392 & $0,004^{*}$ \\
Moist Wound Healing & 15 & 1,40 &, 057 & 5,369 & \\
& & & & & \\
\hline
\end{tabular}




\section{Pembahasan}

Tujuan utama dalam penatalaksanaan ulkus diabetik adalah penutupan luka. Penatalaksanaan ulkus diabetik secara garis besar ditentukan oleh derajat keparahan ulkus, vaskularisasi dan adanya infeksi. Perawatan ulkus diabetik pada dasarnya terdiri dari tiga kompenen utama yaitu debridement, offloading dan penanganan infeksi. Penggunaan balutan yang efektif dan tepat membantu penanganan ulkus diabetik yang optimal. Konsep lain yang dikembangkan dalam perawatan luka dengan menggunakan konsep TIME. Konsep TIME merupakan kerangka kerja dalam perawatan luka meliputi: tissue management, infection /inflammation control, moisture balance dan ephtielial advancement. Adimas (2008).

Pemilihan balutan yang efektif dan tepat merupakan hal yang penting dalam perawatan luka ulkus diabetik. Kondisi lingkungan luka yang bersih dan lembab dapat mencegah dehidrasi jaringan dan kematian sel, akselerasi angiogenesisi dan memungkinkan interaksi antara faktor pertumbuhan dengan sel target. (Parmet, 2005).

Pada penelitian ini, perawatan luka menggunakan dua teknik balutan yaitu
Wet-dry dan Moist Wound Healing. Terlihat perbedaan efektifitas hasil untuk perawatan luka dengan menggunakan metode balutan basah-kering dengan metode balutan lembab. Terlihat metode balutan yang diberikan dapat mempengaruhi proses penyembuhan luka.

Wet-dry Dressing telah menjadi prosedur standar untuk pasien perawatan luka dirumah sakit dan banyak penelitian menunjukan bahwa kasa dressing bukanlah modalutas perawatan luka optimal untu pasien, dressing jasa tidak efektif mendukung penyembuhan optimal (Ovington and Liza, 2001). Perawatan luka dengan menggunakan teknik Wet-dry sangat dipengaruhi oleh suhu lingkungan sekitar. Wet-dry dapat menyebabkan luka menjadi terlalu basah apabila balutan terlalu basah sehingga menyebabkan vaskularisasi pada luka menjadi terganggu dan menyebabkan malserasi. Apabila balutan terlalu kering maka menjadi sulit untuk mengganti balutan luka. Sedangkan untuk teknik balutan modern dressing tidak dipengaruhi oleh suhu lingkungan sekitar karena lapisan balutan tertutup rapat (Morison, 2004). 
Balutan Wet-Dry dengan normal salin menjadi standar baku perawatan luka/ seain itu dapat di gunakan platelet Derived Growth Factor (PDGF), dimana akan meningkatkan penyembuhan luka, PDGD telah menunjukan dapat menstimulasi kemotaksis dan mitogenesis neutrofil, fibroblast dan monosit pada proses penyembuhan luka. Balutan teknik Wet-dry dapat diaplikasikan pada tahap setelah debridemen mekanis yang mana mengurangi dan membuang jaringan nekroktik pada dasar luka. Teknik mekanisme yang sederhana adalah pada palikasi kasa Wet-dry saline gauze. Setelah kain kasa basah diletakkan pada dasar luka dan dibiarkan sampai mengering, debris nekrotik menempel pada kasa dan secara mekanis akan terkelupas dari dasar ketika kasa dilepaskan (Ovingtoand Liza, 2001).

Apabila menggunakan balutan yang basah akan menjadi kering karena dipengaruhi oleh suhu lingkungan sekitar. Balutan menjadi lebih kering akan sangat sulit untuk membuka balutan tersebut saat ingin dilakukan perawatan luka kembali. Jaringanjaringan yang ada disekitar luka akan ikut terangkat pada saat balutan diangkat dari luka. Tidak peduli apakah itu adalah jaringan yang sudah berepitelisasi atau jaringan nekrotik. Untuk jaringan nekrotik sendiri membutuhkan lingkungan luka yang lembab agar dapat mengakat jaringan nekrotik tersebut. Konsistensi jaringan nekrotik adalah keras sehingga butuh balutan yang dapat menjadikan jaringan tersebut lunak. Sedangkan untuk jaringan epitelisasi memiliki sifat yang berbeda dengan jaringan nekrotik. Jaringan epitelisasi sangat lunak sehingga mudah untuk pecah (Mulder, 1995).

Pada penelitian ini dikaji penyembuhan dengan melakukan perawatan luka dengan menggunakan teknik Moist Wound Healing. Moist Wound Healing merupakan suatu metode perawatan luka dengan memberikan lingkungan yang tepat dibutuhkan oleh luka sehingga proses penyembuhan luka sesuai dengan fase penyembuhan luka atau bahkan lebih cepat. Prinsip penyembuhan luka salah satunya adalah kemampuan tubuh untuk menangani trauma jaringan dipengaruhi oleh luasnya kerusakan dan keadaan umum kesehatan tiap orang, maka perawatan dengan menggunakan metode Moist Healing yaitu menyesuaikan apa yang dibutuhkan oleh luka dalam setiap fase penyembuhannya. Sehingga penyembuhan luka dapat menjadi lebih optimal. Hal ini sejalan dengan beberapa 
penelitian yang pernah dilakukan terkait dengan dengan teknik Moist Wound Healing tahun 1962 oleh prof. Dr George D. Winter pada hewan menjelaskan bahwa perawatan luka dengan menggunakan konsep tertutup atau lembab dua kali lebih cepat sembuh dibandingkan dengan perawatan yang dibiarkan dengan kering (Wahidin, 2013).

Menurut teori perawatan luka dengan menggunakan balutan moist healing memberikan lingkungan luka dalam keadaan lembab sehingga dapat mempersiapkan proses penyembuhan luka sesuai dengan waktu yang sudah ditetapkan pada fase penyembuhan luka. Sedangkan penggunaan balutan basah kering menurut teori adalah sebagai balutan dengan menggunakan cara sekunder dan tersier (Ismail dkk, 2009).

Dari hasil penelitian dapat dilihat bahwa proses penyembuhan luka dengan menggunakan teknik moist healing lebih cepat penyembuhannya daripada dengan menggunakan tekhnik balutan basah kering. Hal ini dapat dilihat dari karakteristik luka ulkus diabetik baik pada kelompok Wet-dry yang mengalami perlambatan penyembuhan di bandingkan dengan kelompok perawatan dengan teknik Moist Wound
Healing terdapat perbedaan yang signifikan dari nilai rata-rata pada semua kriteria mencakup ukuran luka, kedalaman luka, keadaan tepi luka, terowongan pada luka, tipe jaringan nekrotik, luas jaringan nekrotik, jenis eksudat, jumlah eksudat, keadaan kulit sekitar luka oedem perifer, ukuran jaringan granulasi, indurasi jaringan perifer dan ukuran epitelisasi (Ovington, 2001). Balutan Moist Wound Healing bersifat lembut dan dapat mengembang apabila luka mempunyai jumlah eksudat yang banyak dan tetap memberikan kesan lembab dan mencegah kontaminasi dari bakteri yang ada diluar luka. Untuk balutan basah kering apabila luka memiliki eksudat dalam jumlah banyak maka harus segera diganti balutannya. Terutama apabila eksudat tersebut sampai merembes keluar dari balutan yang menyebabkan balutan tampak kotor. Selain itu teknik moist healing tidak memberikan nyeri maupun perdarahan saat balutan diangkat dari luka. Sedangkan untuk penggunaan perawatan luka balutan basah kering akan sangat sulit saat ingin membuka balutan tersebut dikarenakan balutan tersebut menjadi kering dan akan menimbulkan nyeri dan juga perdarahan apabila balutan tersebut diangkat (Wahidin, 2013). 
Banyak penelitian lain yang dilakukan untuk mendapatkan penyembuhan luka ulkus diabetik dengan menggunakan media lain, seperti menggunakan madu pada luka. Madu dapat membuat luka menjadi lembab, dan dapat dimanfaatkan untuk mengangkat jaringan mati dan mempercepat proses granulasi pada jaringan, dari hasil penelitiannya menyebutkan bahwa madu membantu proses penyembuhan luka lebih cepat (Suryani \& Supriyono, 2012). Selain didukung dengan teknik perawatan luka yang diberikan tetapi juga dapat memperhatikan prinsip penyembuhan luka lainnya. Pemilihan balutan yang tepat pada perawatan luka dapat lebih efektif dan efisien baik dari segi waktu dan biaya bagi masa perawatan pasien. Pemilihan balutan yang tepat pada perawatan luka dapat lebih efektif dan efisien baik dari segi waktu dan biaya bagi masa perawatan pasien. Pada penelitian yang dilakukan oleh Mulder, Gerit D (1995) menyebutkan bahwa biaya perawatan harian sedikit lebih tinggi dengan metode Moist Wound Healing di bandingkan dengan metode Wet-dry, akan tetapi metode dengan Moist Wound Healing menjadi cara yang lebih efektif dari segi biaya nuntuk mengilangkan luka-luka ini memperhitungkan waktu perawatan.

\section{Kesimpulan}

Dari hasil penelitian yang dilakukan tentang proses penyembuhan luka pada pasien dengan ulkus diabetik dengan menggunakan teknik balutan Wet-dry dan teknik Moist Wound Healing didapatkan hasil uji statistik adanya perbedaan antara proses penyembuhan dengan teknik moist healing dan wet-dry sehingga disimpulkan bahwa pasien dengan ulkus diabetik yang perawatan luka dengan menggunakan moist healing cenderung proses penyembuhan lukanya lebih cepat.

\section{Saran}

Dari kesimpulan diatas penulis memberikan saran sebagai berikut: Dalam Perawatan luka dapat dilakukan dengan teknik balutan Moist Healing yang mempercepat proses penyembuhan luka, meningkatkan laju epitelisasi, dapat menurunkan kejadiaan infeksi, lebih efektif dan efisien dalam biaya juga dapat memberi keuntungan psikologis dan mudah digunakan. Bagi Peneliti lain diharapkan dapat meneruskan penelitian ini dengan menambah jumlah sampel pada kedua kelompok penelitian atau meningkatan penelitian dengan 
Ose, M.I.,Utami, P.A, \& Damayanti, A., Efektivitas Perawatan Luka Teknik Balutan WetDry Dan Moist Wound Healing Pada Penyembuhan Ulkus Diabetik

menggunakan metode eksprimental pada hewan coba dan dapat mengunakan

\section{Referensi}

Adimas. (2008). Cara Perawatan dengan Modern Dressing. http://

Mediacastore.com

Brunner dan Suddarth. (2002). Buku Ajar Keperawatan Medikal Bedah. Jakarta : EGC.

Dahlan Sopiyudin. (2011). Statistik Untuk Kedokteran dan Kesehatan Edisi 5. Jakarta: Salemba Medika Ismail, D. D. S. L., Irawaty, D., \& Haryati, T. S. (2009). Penggunaan Balutan Modern Memperbaiki Proses Penyembuhan Luka Diabetik. Jurnal Kedokteran Brawijaya, 25(1), 32-35.

Istikomah Nurul. (2010). Perbedaan Perawatan Luka Dengan Menggunakan Povodine Iodine 10\% Dan Nacl 0,9\% Terhadap Proses Penyembuhan Luka Pada Pasien Post Operasi Prostatektomi Di Ruang Anggrek Rsud Tugurejo Semarang. Abstrak. Program studi ilmu keperawatan fakultas kedokteran universitas diponegoro semarang media lain yang bersifat moist atau lembab dalam perawatan luka

Julia Mees and Wolf Arif. (2012). Treatment Options for Post operatively infected abdominal wall wound healing by secondary intention. (http://www. ebscohost.co.id di akses 10 oktober 2013)

Mulder, G. D. (1995). Cost-effective managed care: gel versus wet-todry for debridement. Ostomy/wound management, 41(2), 68-70.

Morison, J. Moya. (2004). Manajemen Luka. Jakarta. EGC.

Notoatmodjo, S. (2005). Methodology of Health Research. PT Rineka Reserved, Jakarta, 152-167.

Ovington, L. G. (2001). Hanging wet-todry dressings out to dry. Home Healthcare Now, 19(8), 477-483

Parmet, S., Glass, T. J., \& Glass, R. M. (2005). Diabetic foot ulcers. JAMA, 293(2), 260-260.

Perry dan Potter. (2002). Buku Ajar Fundamental Of Nursing, Volume 1, Edisi 4. Jakarta. EGC. 
Ose, M.I.,Utami, P.A, \& Damayanti, A., Efektivitas Perawatan Luka Teknik Balutan WetDry Dan Moist Wound Healing Pada Penyembuhan Ulkus Diabetik

Supriyanti dkk. (2007). Efektifitas Penggunaan Kompres Metronidazol dan $\mathrm{NaCl} \quad 0.9 \%$ Terhadap Proses Penyembuham luka Diabetik di RSUD Mergono soekarjo

Purwokerto.(http://www.ebscohos t.co.id di akses 10 oktober 2013)

Smeltzer dan Bare. (2002). Keperawatan Medikal Bedah, Volume 2, Edisi 8. Jakarta.EGC

Sylvia A. Prince, Lorraine M. Wilson (2006). Patofisiologi, Edisi 4. Jakarta : EGC.

Suryani, M., \& Supriyono, M. (2012). Efektivitas Pengobatan Madu
Alami Terhadap Penyembuhan Luka Infeksi Kaki Diabetik (Ikd) (Studi Kasus Di Puskesmas Bangetayu Dan Puskesmas Genuk Semarang). Karya Ilmiah S. 1 Ilmu Keperawatan

Soewondo, P., Ferrario, A., \& Tahapary, D. L. (2013). Challenges in diabetes management in Indonesia: a literature review. Globalization and health, 9(1), 63. Wahidin Abun. 2013. Perawatan luka modern dressing. (http ://Mediacostore.com diakses tanggal 13 Maret 2013 